\title{
The Oral Profhesis for the Defect of Palate after Extirpation of Maxillary Cancer and its Effect on Speech
}

\author{
by \\ Tadashi Miyazaki* Yoshihiko Okuno** Norishige Torii** \\ Tokuzo Matsuya* Tamotsu Mimura* Michiomi Sakita* \\ from \\ * The Department of Oral Surgery I, Osaka University Dental School \\ ** The Department of Prosthetic Dentistry II, Osaka University Dental School
}

ABSTRACT

In order to recover the functions of oral cavity, protheses were prepared in two cases whose palates had been extirpated because of maxillary cancer.

The articulatory performances of these two cases were investi gated by means of speech articulation test, analysis of confusion matrix and polygraphic examination.

In this study it was demonstrated quantitatively that these speech aids acted very effectively. And, at the same time, following results were obtained;

1) In the cases who had defect in soft palate, some relationship was observed between the rate of nasal air leakage and the record of articulatory test.

2) The sounds which obtained higher intraoral pressure with speech aid, were pronounced more accurately than before.

3) The patterns of articulatory disorder and the mode of recovery in the case whose posterior margin of soft palate was defected differed from that of the case with uninvolved soft palate.

4) In the former case whose posterior part of soft palate was not involved phonated plosives and fricatives, the more anterior were the articulating points, the more was the nasal air leakage and the lower was the rate of articulatory test. These sounds were pronounced more accurately by use of the speech aid.

5) In the pronunciation of voiceless plosives in the latter case, whose posterior margin of soft palate was involved, the more posterior were the articulating points, the more was the nasal air leakage and the lower was the rate of the articulatory test. In voiced plosives, the more anterior were the articulating points, the less better was the articulation test. In this case, some sounds were not pronounced even with the speech aid. 


\section{上顎腫瘍摘出後における}

\section{顎補縔とその発音回復状態について}

\begin{tabular}{|c|c|c|}
\hline 正* & 奥野 & 善彦** \\
\hline 松矢 篤三* & 三村 & 保* \\
\hline
\end{tabular}

\section{I. 緒 言}

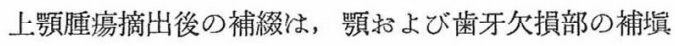
による形態的な回復のみならず, 咀嚼・韮下・発音等口腔 諸機能の回復をる目的とするものでなければならない。

特に, 突然生じた高度の形態的障害と機能的障害挌よ びこれらによって惹起される心理的障害が, 患者の社会 生活を破綻《導く危険もあり, リハビリテーションの上 からも, これらの機能を回復するための勝れた装置が必 要である。しかしながら, この種のいわゆる顎補綴飞特 いては, その久損の範囲が非常に複雑多様であるため, 補経術式を画一的な方法传めることは困難である。し たがって体系的な研究を進め, さらととれとよって補綴 法の改善を求めるとは，尔ず各補経物にある機能的回復 の程度を測定し，これとその補綴法との検討を進めるこ とがまず行なわなければならない。

このような意味から，われわれは従来主として，口蓋 裂等先天性䪽欠損患者飞対する補経を行なって, その発 音・䁩下・咀嚼等の機能の回復括よび外貌の改善をはか り,さらとまたとの効果とついても種々測定して, これ ら補綴物の改良飞努めてきだ方2334)。

今回は, われわれが前述のような目的で作成した補経 物を装着して優れた効果を得た 2 症例飞ついて, 発語音 節明瞭度試験 5 ， 異常音声聴取マトリックス ${ }^{2)}$ による検 查を行ない, あわせて, polygraph とよる構音状態の 検討を試み, speech aid としての効果を確認するとと るに二, 三の興味ある知見を得たので報告する。

\section{II. 測定対象}

測定を行なったのは次の 2 症例であり, いずれも本学 補経学教室に招いて作製した補綴物を, 装着したもので ある。

症例 I

高○敏○ 62 歳

* 大阪大学歯学部口腔外科学第 I 教室

** 大阪大学㧘学部齿科補経学第II 教室

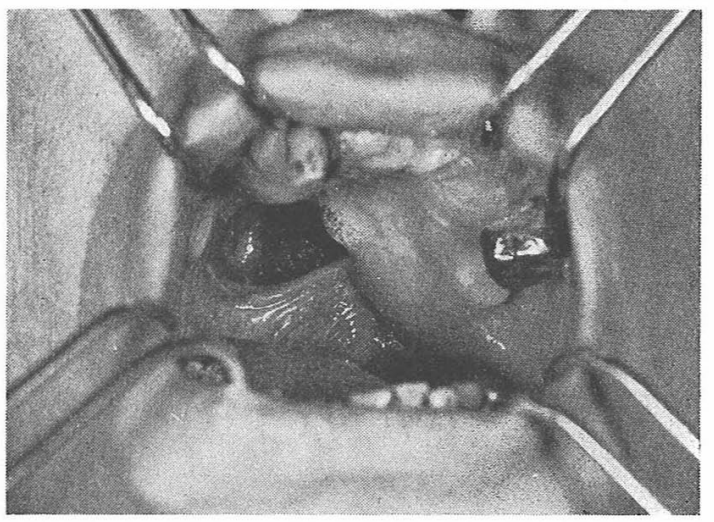

図 1 症例 I の口腔内写真

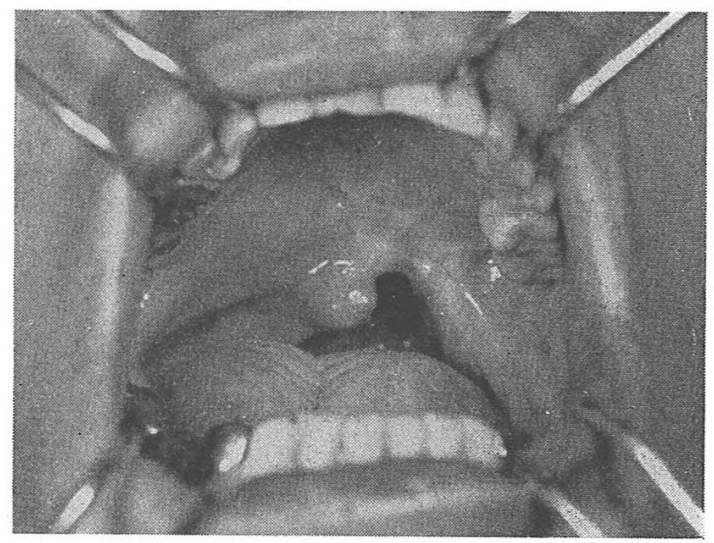

図 2 症例 II の口倿内写真

6年前, 右側上䫓癌摘出術を受け, その結果口蓋部に 久損を有し, 高度の発音障害を主訴己して来院した。欠 損以軟口蓋部扔よび硬口蓋の一部を含さ縦 $30 \mathrm{~mm}$, 横 22 $\mathrm{mm}$ の不正円形を呈し, 久損部後方《は約10 mm の幅で 軟口蓋部が残存している（図 1 )。

症例 II

奥○由○郎 54歳 す

1 年半前, 左側上顎癌腫摘出術を受け, その結果同軟 口蓋部飞欠損を有し高度の発音障害を認める。欠損《軟 


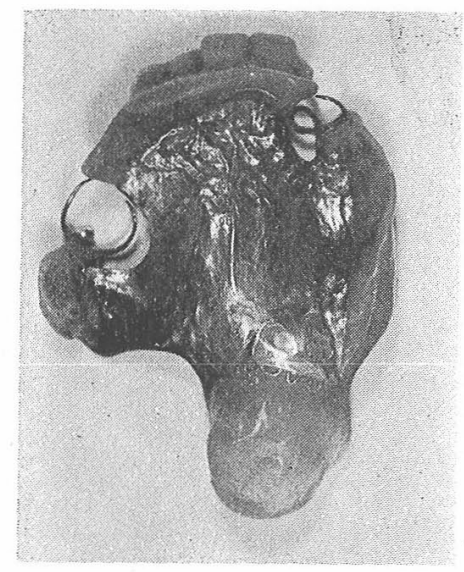

図 3 症例 I の補綴物

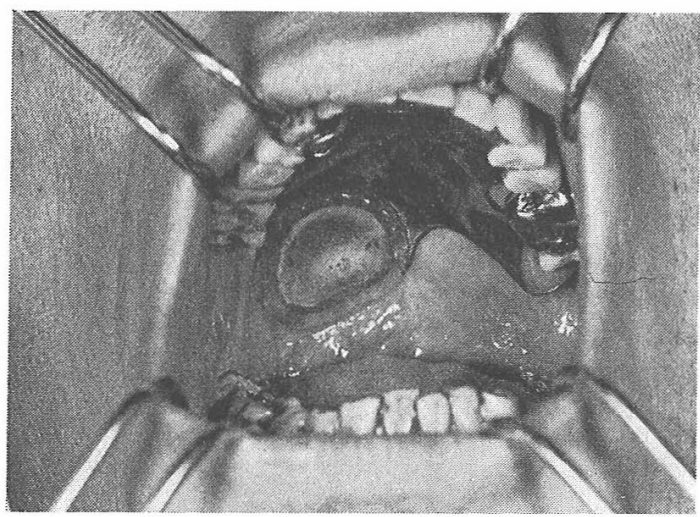

図 5 症例 I の補綴物装着状態

口蓋後縁を含み, 碩口蓋後縁から後方 $8 \mathrm{~mm}$ 正中より左 $10 \mathrm{~mm}$ の点を頂点とし, 後方以やや拡大する扇形を呈し 口蓋垂は残存するが，軟口蓋諸筋の切断のためね偏位を きたしている(図2)。

乙の 2 症例往効し， speech aid 老作成（図 3，4） 装着した（図5，6）。

\section{III. 補緅方法}

まず研究用模型を作製するため歯牙, 硬口蓋, 軟口蓋の 残存部拈よび欠損部にわたってアルギン酸印象材で無圧 印象を行なった。この場合口蓋欠損部の内部,すなわち鼻 腔から咽頭部の印象も十分採得した。トレーは既製トレ 一を使用したが，これの辺縁を適宜削除またはトレーコ ンパウンドで補足延長した。これと石亮を注入して研究 用模型を作製しこの模型上で個人トレーを作製した。こ の個人トレーを患者の口腔内に試適して, 過不足部の調 整を行なった。完成した個人トレーでアルギン酸印象材 そよって久損部周辺招よびその他の軟口蓋部を加圧しな

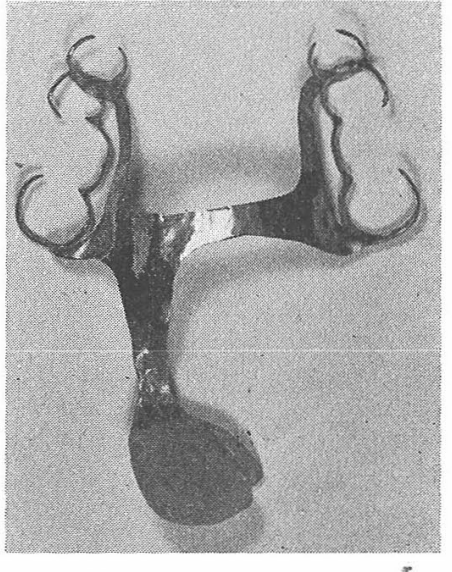

図 4 症例 II の補綴物

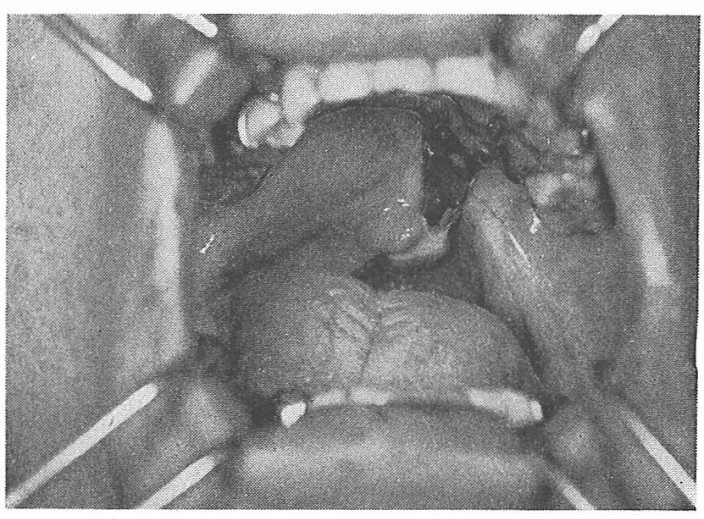

図 6 症例 I の補綴物装着状態

いよう印象し，硬石膏を注入して作業用模型を作製した。 症例Iについてね，残存歯が316 しかないためと㖫 合機能を考穴た palatomaxillary section，火水飞発語 の回復のための palatovelar section をとも亿機能を 発揮できるよう飞 speech aid を設計しなければならな かった。このため飞完成した作業模型上飞図 7 の上うに その維持装置となる部分の設計を行ない，これを $\mathrm{C}_{0}$ 一 $\mathrm{C}_{\mathrm{r}}$ 合金（商品名ライオリウム）飞よって鋳造を行な い，これを口腔試適してその適合状態を確認した後蛽 堤を付着して咬合採得死行ない，咬合器にとりつけて 7654211123457 の人工歯配列を行なって palatomaxillary section を完成させた。㕬合関係が口 腔内で適正であることを確認してから口蓋欠損部 palatovelar sectionの作製沈かかる。なわち isocompound を温湯で軟化して, palatovelar section の維持装 置飞付着してこれを口腔内に挿入して久損部の機能印象 を行なった。欠損部補綴と当っては isocompound の塑 性を利用して硬化しないうちと藏下, 発音させ，あるい 


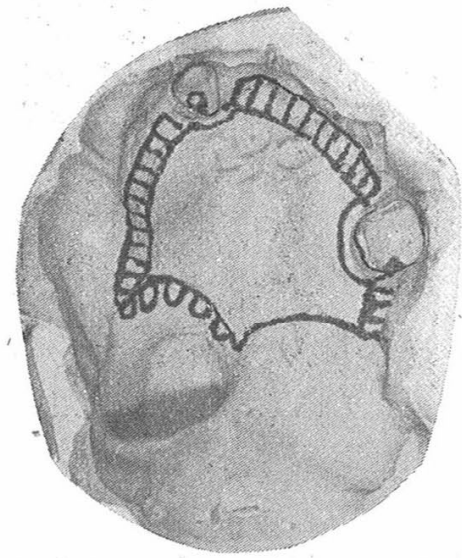

図 7 症例 I の石膏模型
は首を左右に大きく運動させて機能時の印象を採得し， これを透明アクリリックレジンK置換して完成した。こ の症例の欠損部周縁の組織は: 可動性部分が少なかったた めわずかね 久損部を加圧した程度で良好な閉塞ができ た。な㧤，透明アクリリックレジンの栓塞子は重量軽減 のため中空とした。また透明レジンを使用したのは,栓塞 子が欠損部周縁を加圧しすぎた場合，その部分がレジン を通して貧血状態に白く見光，削除の目安とするためで ある。

症例匹については歯牙欠損がないので維持を歯牙に求 めた speech aid (図8) として軟組織欠損を補填乙 た。作製と当っては大部分症例 I の場合と同様であった が，久損部周縁が非常に可動性であったととと咽頭部な で軟口蓋が裂けて状態にあったため熳下，発音時に鼻腔 へ食塊, 呼気が漏出しないようにするため溌音, 與 下時の機能印象を isocompound で慎重飞行なった。印 象採得後の術式は症例 I の場合と同様飞行なった。な掠 pharyngeal section の透明レジンの部分は軽量であっ たので中実のままとした。

\section{IV. 測 定 事項}

症例 I, II とも， speech aid を装着しない状態（以 下, 装着前と略す), speech aid を装着した状態 (以下 装着後と略す)飞执いて次の測定を行なった。な抒，測 定はいずれも speech aid を装着してから1 カ月後に行 なった。

1）発語音節明瞭度試験 ${ }^{5)}$ 扔よび異常音声聴取マトリ ックス ${ }^{6)}$ とよる判定

2) polygraph そよる発語時の構音状態の観察

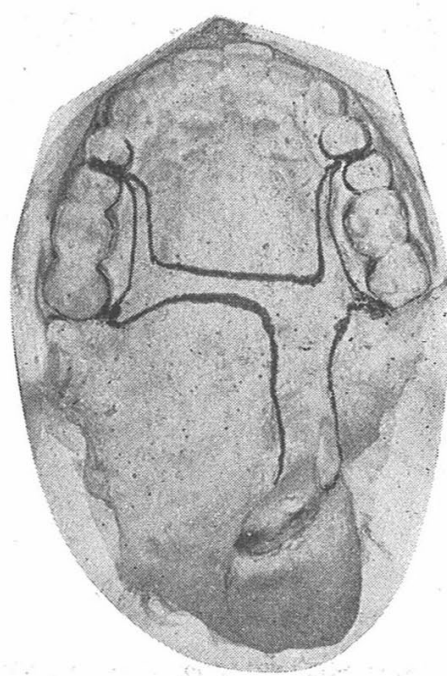

図 8 症例II の石亮模型

\section{V. 測定方法および測定装置}

\section{1. 発語音節明膫度試験 ${ }^{5)}$}

日本語清音, 濁音, 半濁音67音を均等飞含む無意味音 節カード (単音, 二音, 五音節) を防音室内にて患者に 読ませ, 言語治療飞経験を有する検者五名がこれを聞い たな䍹き取りとのうち正しく聞き取れた語音を百分 率で表わす。

さらに，誤って聞き取られた語音についてとれぞれど のような語音飞聞えたかを調へ，異常音声聴取マトリッ クスを作成した。

\section{2. polygraph による発語時構音状態の観察}

測定に用いた装置は日本光電製の多用途監視記録装 たもので, マスク置, 型式 RM-150M とより MFP-1 A 型構成を行なったものに本教室, 宮崎の考案によるマス ク（図9）を接続したものである。このマスクは全麻用 マスクを改造したむので, マスク内部に隔壁を設け鼻腔 からの呼気之, 口腔からの呼気は完全分離されそれぞ れ別々飞, トランスデニーサー (MFP-1 T ) 飞導かれる。 圧力測定用チューブは, 外径 $3 \mathrm{~mm}$, 内径 $2 \mathrm{~mm}$ の ビニールチューブで, マスクを貫通して増幅器, PR-2 -Pに接続する。マスクの口腔側内面に小型マイクが取付 けられ，発声を記録すると同時に，VUメーター飞接続 して音量規制用いられる。

この装置により, 発語時の口腔からの呼気流速拉よび 漏出量, 鼻腔からの呼気流速持よび漏出量, 口腔内圧, 鼻腔内圧，音声の同時測定記録を行なった。 


\section{VI. 測 定 結 果}

\section{1. 発語音節明膫度試験}

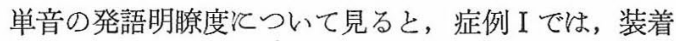
前 $54 \%$ のものが，装着後93\% 亿回復し，症例II で忙 $43 \%$ のものが75\%に回復している。これを各行別見ると，

a） 青，鼻音招よび八行音：装着前でも浪とえど障 害はなく， speech aid 装着後も大きな変化な認められ なかっ它。

b) 摩擦音拉よびラ行音 : 症例 I では 53〜87\%のもの が90\%以上飞, 症例 II では30\%以下のものが80\%以上と 著明な回復を認めた。

c）無声破裂音：症例 I では 33〜 56\%のものが，93\% 以上飞回復しているのに齐して, 症例II ではガ行音に著 明な回復を認めるほか心，いちじるしい回復は認めなか った。

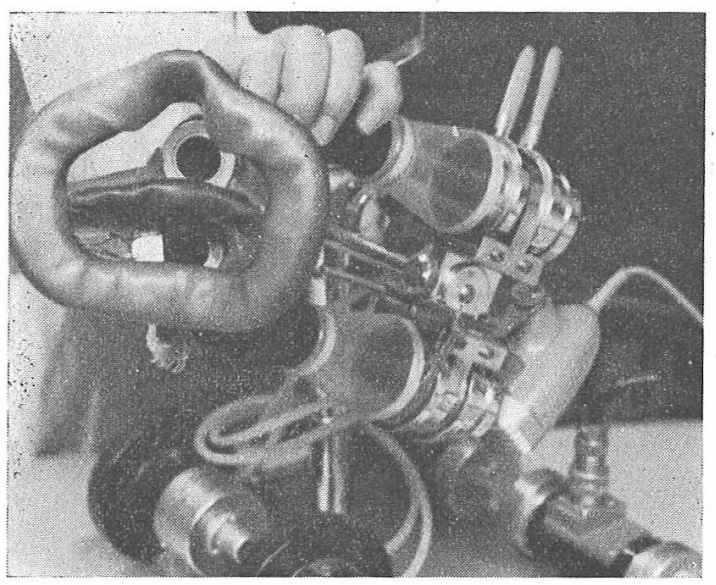

図９宦崎考案によるマスク

\section{2. 異常音声聴取マトリックスによる異聴傾向の 判定 (表 1)}

異常音声聴取マトリックスによれば，症例凹の装着前 では，無声破裂，摩擦音のほとんどすべてが八行音飞異 聴され，う行音秎よび有声破裂，摩擦音のすべてが鼻音 飞異恥されていた。装着後流これらが改善され，ただバ 行音がマ行音異聴されたのみであった。症例 I 飞も同 㥞の傾向を認わたが，異聴の程度山低く，八行音执与び 鼻音へ集中する傾向も，症例川 后ど著明ではなかった。

3. polygraph による測定結果（表 2)

a）呼気漏出量：発語にさいし消費する呼気量はすべ ての語音について，正常人より高い值を示し，装着後か なり低下する。

b) 鼻腔漏出率：症例 I では, 装着前飞比し 装着後は いちじるしく低下し， speech aid そより口腔鼻腔の閉
鎖が有効に行なわれていることがわかった。すなわら， 無声破裂音，無声摩擦音飞扮いては，48～84\%のものが 18～31\% 有声破裂，摩擦音飞物いては44～63\%のむ のが40～47\%に低下している。症例IIでは，無声破裂音 では低下を認めたが，有声破裂音バ行音で屰朔大とな っている。

c ）口腔内圧：症例 I の無声破裂音発語時の口腔内圧 ほ，装着前 $7 \mathrm{cmH}_{2} \mathrm{O}$ 以下であったものが装着後 $11 \mathrm{~cm}$ $\mathrm{H}_{2} \mathrm{O}$ 以上江, 有声破裂音で补 $3 \mathrm{cmH}_{2} \mathrm{O}$ 以下のものが $6 \mathrm{cmH}_{2} \mathrm{O}$ 以上飞, 有声, 無声摩擦音で社 $7 \mathrm{cmH}_{2} \mathrm{O}$ 以下 のものが $11 \mathrm{cmH}_{2} \mathrm{O}$ 以上飞回復し，いずれも正常者平均 値を上回る值となった。症例 II の無声破裂音, 無声摩擦音 で装着前 $8 \mathrm{cmH}_{2} \mathrm{O}$ 以下のもので, 装着後 $10 \mathrm{cmH}_{2} \mathrm{O}$ 以上飞回復して正常者の值飞達していたが，バ行音では $1.0 \mathrm{cmH}_{2} \mathrm{O}$ が $3.9 \mathrm{cmH}_{2} \mathrm{O}$ と回復が著明でななかった。

表 1 発語音節明膫度試験（単音）

\begin{tabular}{|c|c|c|c|c|}
\hline & \multicolumn{2}{|c|}{ 症 例 I } & \multicolumn{2}{|c|}{ 症 例 II } \\
\hline & 装着前 & 装着後 & 装着前 & 装着後 \\
\hline 厂 行音 & $93 \%$ & $100 \%$ & $87 \%$ & $100 \%$ \\
\hline 八 & 100 & 100 & 100 & 80 \\
\hline$\checkmark$ & 80 & 100 & 100 & 80 \\
\hline ナ & 80 & 80 & 100 & 80 \\
\hline サ & 53 & 100 & 27 & 80 \\
\hline ザ & 60 & 93 & 0 & 87 \\
\hline ラ & 87 & 93 & 7 & 80 \\
\hline パ & 40 & 73 & 47 & 80 \\
\hline タ & 66 & 93 & 47 & 93 \\
\hline 力 & 73 & 86 & 0 & 80 \\
\hline バ & 33 & 93 & 0 & 20 \\
\hline ダ & 56 & 100 & 33 & 44 \\
\hline ガ & 40 & 93 & 40 & 80 \\
\hline 平 均 & 54 & 93 & 43 & 75 \\
\hline
\end{tabular}

\section{VIII. 考 察}

從来, speech aid の効果の判定には, 会話による発 語障害の有無の判定 ${ }^{7}$, 発語音節明膫度試験 ${ }^{899}$, sonagraph 飞上る分析 ${ }^{9)}$, confusion-matrix 飞よる検討? など，音声を対象とした検索が主に行なわれ，さらに，

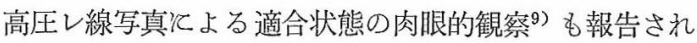
ている。しかし，発語時の構音状態を定量的に測定して speech aid の効果孝確認したものは見当らない。今回, われわれ《発語音節明膫度試験, 異常音声聴取マトリッ クスによる検討を行なうとともに，発語時構音状態ねつ いて, 口腔内圧, 口腔掠よび鼻腔からの呼気漏出状態を 
同時測定を行なって上て述べた結果を得た。

以下, これらの結果を総合的洘察すると, 軟口蓋欠 損状態では, 特に破裂音, 摩擦音飞障害が著明で, 発語 音節明瞭度が低く，正常人では，鼻腔漏出を認めないの に対し, 症例 I, II とも, 多量の鼻腔漏出を認める。ま た, 装着前, 症例 I と括いては, 同一群内の語音では, 構音点が前にある語音程, 明瞭度が低く鼻腔漏出率が高 い傾向を認めるが, 口腔内圧上昇の不足と, 明瞭度の低 下とは, 必ずしも一致していない。症例Iでは, 無声破 裂音では構音点が後方にある語音程明瞭度が低く鼻腔漏
める。一方軟口蓋後縁部が, 構音沈わめて重要な役割 を果していることを示している。 speech aid 装着後, 摩擦音, 無声破裂音では著明な明瞭度の回復を認わるの に対して, 有声破裂音では構音点が前方にある語音程, 明瞭度の回復が低い。このように, 回復状態ガ語音によ りいちじるしい差異を生じるのは，軟口蓋後縁部执よび 舌根部の位置が語音によって異なるためと考えられる。 すなわち, 本症例IIの speech aid では力行音, が行音 のごとく, 舌根部ならびそ軟口蓋後縁部が後上方へ挙上 した状態に括いて，最も有効に鼻咽閉鎖が行なわれ，乙

表 2 polygraph による測定結果

\begin{tabular}{|c|c|c|c|c|c|c|c|c|c|c|}
\hline & & & \multicolumn{3}{|c|}{ 無声破裂音 } & \multicolumn{3}{|c|}{ 有声破裂音 } & \multicolumn{2}{|c|}{ 摩 擦 音 } \\
\hline & & & パ & タ & カ & バ & ダ & ガ & サ & ザ \\
\hline \multirow{8}{*}{$\begin{array}{c}\text { 症 } \\
\text { 例 } \\
\text { I }\end{array}$} & \multirow{4}{*}{ 装 着 前 } & （明瞭度 ％) & 40 & 67 & 73 & 33 & 56 & 40 & 53 & 60 \\
\hline & & 呼気漏出量 Cc & 87 & 146 & 55 & 119 & 140 & 89 & 272 & 122 \\
\hline & & 鼻漏出率 \% & 84 & 82 & 64 & 63 & 44 & 45 & 49 & 51 \\
\hline & & 口腔内王 $\mathrm{cmH}_{2} \mathrm{O}$ & 3.9 & 6.9 & 6.2 & 1.8 & 3.0 & 0.3 & 2.6 & 6.6 \\
\hline & \multirow{4}{*}{ 装 着 後 } & （明瞭度） & 73 & 93 & 87 & 90 & 100 & 93 & 100 & 93 \\
\hline & & 呼気漏出量 & 82 & 56 & 49 & 76 & 42 & 41 & 148 & 68 \\
\hline & & 鼻 漏出率 & 21 & 30 & 31 & 41 & 40 & 41 & 18 & 47 \\
\hline & & 口腔内王 & 11.8 & 12.0 & 12.0 & 9.5 & 6.7 & 6.3 & 12.4 & 11.0 \\
\hline \multirow{8}{*}{$\begin{array}{l}\text { 症 } \\
\text { 例 } \\
\text { II }\end{array}$} & \multirow{4}{*}{ 装 着 前 } & （明瞭度） & 47 & 47 & 0 & 0 & 33 & 40 & 27 & 0 \\
\hline & & 呼気漏出量 & 122 & 100 & 107 & 30 & 一 & 一 & 160 & 一 \\
\hline & & 鼻漏出率 & 41 & 54 & 55 & 33 & 一 & 一 & 37 & 一 \\
\hline & & 口腔内王 & 7.9 & 5.3 & 6.6 & 1.0 & 一 & 一 & 5.3 & - \\
\hline & \multirow{4}{*}{ 装 着 後 } & （明瞭度） & 80 & 93 & 80 & 20 & 44 & 80 & 80 & 89 \\
\hline & & 呼気漏出量 & 110 & 75 & 53 & 54 & 一 & - & 147 & - \\
\hline & & 鼻 漏 出率 & 30 & 36 & 25 & 44 & - & 一 & 25 & 一 \\
\hline & & 口腔 内圧 & 10.5 & 12.9 & 17.7 & 3.9 & 一 & - & 12.9 & 一 \\
\hline & 常 者 & 口腔内圧 & 9.5 & 9.3 & & 5.0 & & & 5.3 & 7.9 \\
\hline
\end{tabular}

註. 鼻漏出率 $=\frac{\text { 鼻腟漏出量 }}{\text { 乎気漏出量 }} \times 100$

出率が大である。症例 I, II とも speech aid 装着後は 口腔内圧の著明な上昇を認める語音は明瞭度の回復が良 好である。また, 装着後同様と口腔内圧の上昇を認める 語音に和いては, 呼気消費量が著明に減少する語音のほ ろが, 装着後も多量の㭔気を要する語音よりも明瞭度が 高い。これは, 発語にさいして, 口腔内圧を上昇させよ うとする努力が軽減されることにより，正しい発語が可 能になるものの考えられる。

症例 I , IIの欠損部位を比較し考察すれば，軟口蓋後 縁部の残存する症例 I V沶いては，無声破裂音，摩擦音 そおいて構音点が前方位する語音程明瞭度が低かった ものが, speech aid 装着後, いずれも著明な回復を認
たがって舌根部招よび軟口盍後縁部の挙上されないバ行 音などル和いては適合しにくく，空隙を生じ，そのため 飞有效働きえないものと考えられる。

\section{VIII. 結 論}

上顎癌腫摘出患者 2 例について speech aid としての 補経物を作成し，発語の改善について発語音節明膫度試 験および異常音声聴取マトリックスによる判定拝よび polygraph による 発語時の構音状態の観察を行なって 次のような結果を得た。

1）㳄口蓋部々欠損がある場合, 発語時呼気の鼻腔漏 出率と明膫度の低下とに相関関係がある。 
2） speech aid 装着時, 容易飞口腔内圧が上昇する 音では, 明瞭度の回復が良好である。

3）久損が軟口蓋後縁を含さ症例と含まない症例では 障害の状態, 回復の状態に差異がある。

4) 久損が軟口蓋後縁を含まない場合は, 破裂音, 摩 擦音では構音点が欠損部より前方にある語音程, 鼻腔漏 出率は大きく, 明瞭度は低い。 speech aid 装着により 明瞭度はいずれの語音も著明に回復する。

5）欠損が軟口蓋後縁を含む症例でね，無声破裂音で は構音点が後方にある程鼻腔漏出率が大で, 明瞭度も低 い值を示す。有声破裂音では構音点が前方にある音程障 害が強い。 speech aid 装着により, 著明に回復し易い 音と，回復しない音とがある。

\section{文 献}

1）河合庄治郎・他：乘唇口蓋裂患者の手術後の補
綴とその效果について，歯科時報， 16, 1 10, 1962. 2) 河合庄治郎・他：鬼辰口蓋裂の手術後に 於ける補綴例, 日本歯科評論, 191, 22～26, 1957. 3）宮崎正・他：Attachmentを利用した Speech aid Appliance とその発音効果に及ぼす影響につい $\tau$, 日本補経歯科学雑誌, 4, 7 14, 1960. 4) 奥 野善彦・他：顎補綴物 (Speech aid) の嚥下機能障 害改善についてのX線映画的研究, 日本補䌡歯科学 雑誌, 9, 98 105, 1965. 5) 高寄昭：口蓋裂異常 音声の語音発語明瞭度検査ならびに口蓋裂の手術時 期に関する研究, 大阪大学歯学雑誌, $9,79 \sim 90$, 1964. 6) 日本音響学会明瞭度委員会編：明瞭度試 験法の規準，1959.7) 片岡保夫・他：上顎骨欠如 に対する補綴例, 歯科学報, 61, 560, 1961。 8) 能美貞昭 - 他：上顎全摘後の音声 (2), 日本耳鼻咽 喉科学会会報, 65, 1293, 1962.99) 小野克已：軟 口蓋切除患者の構音と補経, 日本口腔科学会雑誌, 10, $274 \sim 275,1961$.

\section{《投 稿, 掲載 規定》}

○投稿について(ただし，投稿は当学会員に限ります）

（1）編集委員会が寄稿を依頼した綜説・展望・技術解説などは希望枚数以内にまとめて下さい。原著は 400字詰原稿用紙 20 枚, 図表 5 枚以内は無料で揭載し, 規定を超過した場合には超過分に要した一切 の実費をいただきます。原著以外の投稿は予め編集委員に連絡し，枚数の指定を受けてください。

（2）原稿は平がな，口語文，現代かなづかいとし，外国文字はタイプするかまたは印刷体で明瞭に記入の こと。

（3）原稿には欧文の題名・所属・氏名をつけてください。

(4) 原著には 400 語以内の欧文抄録および邦訳をかならずつけてください。

（5）度量衡は $\mathrm{mm}, \mathrm{cm}, \mathrm{m}, \mathrm{m} l, l, \mu \mathrm{g}, \mathrm{g}, \mathrm{C}, \mathrm{mEq}$ などとする。慣例上 CGS 単位以外を使用する場合 には括弧内にCGS 単位に換算した数值を記入すること。

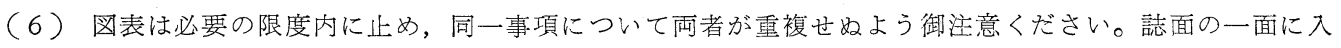
り得ない膨大な表は組めません。

（7）引用文献は少なくとも次の事項を明らかにして下さい。 雑誌の場合一一著者名: 誌名, 巻, 頁, 発行年 (西暦)

例 勝沼晴雄・他：日本公衛誌, 10, 95, 1963.

Ward, L. E. : Arth. \& Rheum., 6, 650, 1963.

単行本の場合一一著者名: 書名 (必要あれば引用頁), 版数, 発行所, 発行年

例 Daniels, L. et al : Muscle Testing, 2nd ed., W.B. Saunders, Philadelphia, 1959.

（８）著者校正は原則として1回とし，校正は赤インクでお願いします。校正の方法の詳細は医学畫院 P R 課にお申し出になれば「執筆・校正のしおり」をお送りいたします。

\section{○掲載について}

（1）寄稿論文の採否は編集委員会で決定し，多少の字句の訂正もすることがあります。なお，揭載予定の 原稿であっても投稿規定に反する場合には一部の変更をお願いすることがあります。

（2）別刷は50部を無料で，それ超える分については著者の希望により実費でさしあげます。

\section{○原稿送付先}

東京都交京区目白台 3-28-6

東京大学医学部付属病院分院内 日本リハビリテーション医学会 宛 